CASE NOTE

\title{
SECRETARY OF STATE FOR THE HOME DEPARTMENT $v E 3$ AND N3 [2019] EWCA CIV 2020, [2020] 1 WLR 1098
}

\author{
ERIC FRIPP*
}

TABLE OF CONTENTS

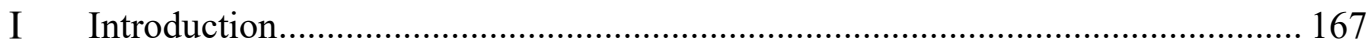

II Secretary of State for the Home Department $v$ E3 and N3 .................................. 168

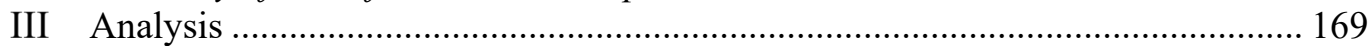

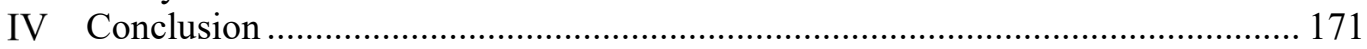

\section{INTRODUCTION}

In England and Wales, s 40(2) of the British Nationality Act 1981 ('BNA 1981') ${ }^{1}$ gives power to the Secretary of State for the Home Department to make an order to deprive a person of 'citizenship status', if satisfied that deprivation is conducive to the public good. However, s 40(4) provides that the Secretary of State may not do so if satisfied that the making of such an order would render the affected person stateless.

The breadth of the administrative power at s 40(2) BNA 1981 means that often the decisive question is whether s 40(4) prevents the making of a deprivation order. Despite the apparent simplicity of the question raised by s 40(4), the complexity of the legal issues arising from it has led to a substantial jurisprudence including two appeals to the United Kingdom Supreme Court. ${ }^{2}$ A recent decision of the Court of Appeal (Civil Division) ('CA'), in Secretary of State for the Home Department $v E 3$ and N3 ('E3 and N3') ${ }^{3}$ should focus attention on an important point regarding what has been found to be an initial burden of proof imposed upon the Secretary of State by s 40(4) BNA 1981.

The general standard of proof in civil proceedings in the UK is the balance of probabilities, often referred to as the 'civil standard of proof' to distinguish it from the criminal standard of proof beyond reasonable doubt. In $R$ (on the application of D) $v$ Life Sentence Review Commissioners, the House of Lords held that there was a single civil standard by which the Court would be satisfied of a fact, if it considered that on the evidence something was more likely than not. ${ }^{4}$

* $\quad$ Eric Fripp is a barrister at Lamb Building, Elm Court, Temple, London EC4Y, and a Senior Visiting Fellow in the Refugee Law Initiative, School of Advanced Study, University of London. He is General Editor of The Law and Practice of Expulsion and Exclusion from the United Kingdom (Hart, Oxford, 2014) and author of Nationality and Statelessness in the International Law of Refugee Status (Hart, 2016).

1 (UK) ('BNA 1981').

2 Secretary of State for the Home Department $v$ Al-Jedda [2013] UKSC 62, [2014] 1 AC 253 ('Al-Jedda'); Pham v Secretary of State for the Home Department [2015] 3 All ER 1015 ('Pham').

3 [2019] EWCA Civ 2020, 1 WLR 1098 ('E3 and N3').

4 See $R$ (on the application of D) v Life Sentence Review Commissioners [2008] UKHL 33, [2008] NI 292, [23] and the subsequent discussion of Carswell LJ on the debate surrounding the balance of probabilities. 
In some public law cases though, the approach to be followed depends upon a statutory formulation rather than a straightforward application of the burden and standard of proof. This is the case as regards deprivation of nationality under s 40 BNA 1981. By s 40(4), the Secretary of State, if 'satisfied' that a s 40(2) order 'would make a person stateless', cannot go on to make such an order.

In AS (Guinea) $v$ Secretary of State for the Home Department, 5 a deportation case in which the appellant claimed to be stateless, the CA confirmed that the standard of proof applicable in determining whether someone would be stateless was the ordinary civil standard. By contrast, in deprivation cases s 40(2) BNA 1981 requires a two-step approach. In Hashi $v$ Secretary of State for the Home Department ('Hashi'), ${ }^{6}$ the weakness of the evidence adduced to support the appellant's claim was held to be such that the precise approach to standard of proof did not matter. The CA found however that the Secretary of State had to show satisfaction that her order would not make Mr Hashi stateless, and then he had to show that the Secretary of State had been mistaken. ${ }^{7}$

This statement of the law was then followed by the Special Immigration Appeals Commission ('SIAC') in $R 3 v$ Secretary of State for the Home Department. ${ }^{8}$

\section{SECRETARY OF STATE FOR THE HOME DEPARTMENT V E3 AND N3}

In $E 3$ and N3, the Secretary of State had given notice of decisions under s 40(2) BNA 1981 to two British citizens of Bangladeshi origin. ${ }^{9}$ Each entered notice of appeal on grounds including the claim that, if deprived of British citizenship, he would be stateless. ${ }^{10}$ The appeals were considered initially in SIAC. ${ }^{11}$ It drew on evidence from two experts on Bangladeshi nationality law. ${ }^{12}$ In addition, the Secretary of State relied upon a note verbale of the Bangladeshi authorities concerning the nationality laws of Bangladesh. ${ }^{13}$ The Commission found the expert evidence 'sub-optimal' because both relied on distinct sources on Bangladeshi law that led to different viewpoints. Where the experts disagreed, the Commission preferred the evidence of the appellants' expert as to the relevant law and practice. ${ }^{14}$ The Commission then turned to the note verbale, whose content suggested that the Bangladeshi state's interpretation of its nationality laws, or application of these in practice, was one by which Bangladeshi nationality arose in the cases. ${ }^{15}$ The Commission held that the burden of proof on the subject matter of the note verbale lay with the Secretary of State, and had not been discharged. ${ }^{16}$

5 AS (Guinea) v Secretary of State for the Home Department [2018] EWCA Civ 2234, [2019] INLR 157, [59]. See also Judith Carter, 'AS (Guinea) v Secretary of State for the Home Department [2018] EWCA CIV 2234’ (2019) 1(2) Statelessness and Citizenship Review 336, 342.

6 Hashi $v$ Secretary of State for the Home Department [2016] EWCA Civ 1136 ('Hashi').

7 ibid [23]-[24].

$8 \quad$ R3 v Secretary of State for the Home Department [2018] UKSIAC SC/150/2018.

$9 \quad$ E3 and N3 (n 3) [6].

10 ibid [7].

11 ibid [1].

12 ibid [15].

13 E3 and N3 (n 3) [18].

14 ibid [22].

15 ibid [23].

16 ibid. 
The Secretary of State appealed to the CA. Allowing that appeal and remitting the proceeding back to the Commission for reconsideration, ${ }^{17}$ the Court accepted that once the Secretary of State has demonstrated that the deprivation order will not render the individual stateless, the burden of proving that the individual will be rendered stateless is on the individual. ${ }^{18}$

The Court held inter alia that the burden of proof was, as described in the Hashi decision, potentially divided into two separate parts. ${ }^{19}$ At the first of these the burden lay upon the Secretary of State to demonstrate satisfaction that the order would not make the appellant stateless. Of this stage Longmore LJ had observed in Hashi, 'That is a comparatively easy burden to discharge and Mr Hashi does not challenge that she was so satisfied'. ${ }^{20}$ At the second, the burden moved to the subject of the order to prove error 'again as described by Longmore LJ in Hashi 'Mr Hashi is entitled to and does assert that she was wrong to be so satisfied and on that question he must have the relevant burden of proof'. ${ }^{21}$ This transfer of the burden followed given that, as SIAC said at [5] of its judgment in Abu Hamza, the appellant is alleging that there should be an exception to a general power. ${ }^{22}$

An issue of particular importance raised by the decision is the nature of the initial requirement that the Secretary of State be satisfied that the order will not make the affected person stateless.

\section{ANALYSIS}

In $E 3$ and $N 3$ the CA referred to the decision of the United Kingdom Supreme Court in Al-Jedda $v$ Secretary of State for the Home Department ('Al-Jedda'). ${ }^{23}$ In that case, the Secretary of State had appealed to the Supreme Court based on the CA's finding that a decision leading to statelessness could only be taken upon a strict assessment of the individual's status as at the date of the order. ${ }^{24}$ An appeal could not turn on whether an individual was stateless allegedly by reason of his or her failure to take steps to retain a former nationality, or gain a new one. ${ }^{25}$ The Supreme Court rejected the appeal. ${ }^{26}$

In Al-Jedda the government had argued that the word 'satisfied' in s 40(4) BNA 1981 meant the Secretary of State had a broader span of judgment, rather than one limited to the single issue of nationality (or potential absence thereof) at the time of the order. That submission was rejected in terms by Lord Wilson: 'Irrespective ... of whether the word "satisfied" in subsection (4) can sensibly be afforded any significance at all ... it cannot bear the weight which [Counsel for the Secretary of State] seeks to ascribe to it'. ${ }^{27}$

17 E3 and N3 and Secretary of State for the Home Department [2018] UKSIAC SC/138/2017 and 146/2017, [99]-[102].

18 E3 and N3 (n 3) [55].

19 ibid [32], citing Hashi (n 6) [23]-[24].

20 ibid [32], citing Hashi (n 6) [23].

21 ibid [32], citing Hashi (n 6) [24].

$22 E 3$ and N3 (n 3) [58], citing Abu Hamza and Secretary of State for the Home Department [2003] UKSIAC SC23/2003 [5].

23 E3 and N3 (n 3) [57]-[59], citing Al-Jedda (n 2) [30] (Lord Wilson JSC).

24 Al-Jedda (n 2) [1].

25 ibid [32]-[34].

26 ibid

27 ibid [30]. 
In E3 and N3, the Court plainly appreciated the different context of Lord Wilson's observations in Al-Jedda. ${ }^{28}$ But the effect of the statutory duty is nevertheless identified in minimising terms, with the difference to Al-Jedda being that 'satisfied' had to have at least some minimal significance, and citing Hashi, the initial 'satisfied' burden would be 'comparatively easy' for the Secretary of State to comply with. ${ }^{29}$

This, however, seems to undermine the balance built into the statute by inclusion of the s 40(4) BNA 1981 restraint. It also creates potential friction with a line of domestic administrative law authorities imposing objective standards, where judgments are taken for the State under provisions that admit of judgment or satisfaction as to a particular matter.

In Office of Fair Trading $v$ IBA Health Ltd, the CA held the statutory phrase 'is satisfied' meant that the Court must enquire into whether that belief was 'reasonable and objectively justified by relevant facts'. ${ }^{30}$ In Secretary of State for Education and Science v Tameside Metropolitan Borough Council ('Tameside'), the House of Lords considered an appeal concerned with a requirement that the Secretary of State be 'satisfied', that a local authority or school governors 'have acted or are proposing to act unreasonably with respect to the exercise of any power conferred or the performance of any duty imposed by or under this Act'. ${ }^{31}$ Of the 'subjective language' employed in the statute, Lord Wilberforce observed:

This form of section is quite well known, and at first sight might seem to exclude judicial review. Sections in this form may, no doubt, exclude judicial review on what is or has become a matter of pure judgment. But I do not think that they go further than that. If a judgment requires, before it can be made, the existence of some facts, then, although the evaluation of those facts is for the Secretary of State alone, the court must inquire whether those facts exist, and have been taken into account, whether the judgment has been made upon a proper self-direction as to those facts, whether the judgment has not been made upon other facts which ought not to have been taken into account. If these requirements are not met, then the exercise of judgment, however bona fide it may be, becomes capable of challenge. ${ }^{32}$

In Secretary of State for the Home Department v Javed ('Javed'), accelerated appeal procedures applied for persons originating in states designated by order of the Secretary of State as those 'in which it appears to him that there is in general no serious risk of persecution'. ${ }^{33}$ His order designating Pakistan was found unlawful at first instance and he appealed to the CA. The judgment of the Court, delivered by Lord Phillips MR, citied the Tameside case and again rejected the proposition that the language 'in which it appears to him' legitimised subjective or precipitate judgment:

The Secretary of State did not argue that the words 'it appears to him that' empowered ... a purely subjective approach to designation; such an argument would have been untenable: see [Tameside] per Lord Wilberforce. The Act only entitled the Home Secretary to designate countries or territories in respect of which

$28 \quad$ E3 and N3 (n 3) [57].

29 ibid [59], citing Hashi (n 6) [23] (emphasis added).

30 [2004] EWCA Civ 142, [45].

31 [1976] 3 WLR 641.

32 ibid 665.

$33 R$ (Javed) $v$ Secretary of State for the Home Department [2001] EWCA Civ 789, [2002] QB $129,[55]$. 
the evidence available to him was such as to enable him rationally to conclude that there was 'in general no serious risk of persecution'. 34

The principle which runs through these cases leaves it to the Secretary of State to take a view, so long as this follows an adequate procedure and is rationally supported on the evidence. ${ }^{35}$ It does not, for instance, require the Secretary of State not to be satisfied of a relevant fact if reasonable alternative views exist. But it does arguably point to a more searching approach than has been applied in s 40 $B N A 1981$ cases to date. And a more penetrative approach is arguably strongly supported given importance of the subject matter — citizenship status - is judicially acknowledged. Precisely this has occurred in another deprivation of citizenship case in the Supreme Court, Pham v Secretary of State for the Home Department. ${ }^{36}$ Lord Carnwath JSC (with whom Lord Neuberger PSC, Baroness Hale DPSC and Lord Wilson JSC agreed) observed that the sensitivity of judicial review to context '[applies] with even greater force in my view in a case such as the present where the issue concerns the removal of a status as fundamental, in domestic, European and international law, as that of citizenship' ${ }^{37}$ Nor does the statutory appeal context in a case such as E3 and N3 provide a valid basis for distinction from the approach in the Tameside and Javed cases. ${ }^{38}$

\section{CONCLUSION}

The decision of the Court in E3 and N3 confirms and brings together previous threads of jurisprudence regarding the standard of proof in appeals against deprivation of British citizenship status under s 40(2) BNA 1981. It reconfirms that once the Secretary of State has concluded that s 40(4) does not prevent the making of an order under s 40(2), the burden shifts to the affected individual. In addition, it shows relatively scanty examination of the preliminary duty upon the Secretary of State, and supports the earlier characterisation of this in Hashi as 'a comparatively easy burden to discharge'. ${ }^{39}$ In doing so it leaves unaddressed and highlights — no doubt unintentionally — an apparent friction with the wider administrative law treatment of measures invoking subjective judgment by the executive.

34 ibid.

35 See also Michael Fordham, Judicial Review Handbook (6 ${ }^{\text {th }}$ edn, Hart 2012) 449-52 [39.3.6].

36 Pham (n 2).

37 ibid [60].

38 The approach of a court or tribunal to identification of error of law, on judicial review and on statutory appeal respectively, has long been held to be similar. E v Secretary of State for the Home Department [2004] EWCA Civ 49, [42]: 'it has become a generally safe working rule that the substantive grounds for intervention are identical'.

39 E3 and N3 (n 3) [32], citing Hashi (n 6) [23]. 